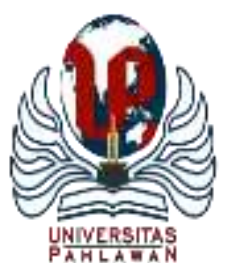

\title{
JURNALBASICEDU
}

Volume 6 Nomor 1 Tahun 2022 Halaman 656 - 663

Research \& Learningin Elementary Education

https://jbasic.org/index.php/basicedu

\section{Kelayakan Buku Lembar Kerja Peserta Didik Berbasis Problem Based Learning (PBL) pada Pembelajaran Tatap Muka Terbatas di Sekolah Dasar}

\author{
Andi Arfianto ${ }^{1 凶}$, Sutama $^{2}$, Achmad Fathoni ${ }^{3}$ \\ Magister Pendidikan Dasar, Universitas Muhammadiyah Surakarta, Indonesia ${ }^{1,2,3}$ \\ E-mail: Andi.arfianto.aa@gmail.com ${ }^{1}, \underline{\text { Sutama@ums.ac.id }}{ }^{2}, \underline{\text { af267@ums.ac.id }}^{3}$
}

\begin{abstract}
Abstrak
Penelitian pada artikel ini secara umum bertujuan untuk menguji kelayakan buku LKPD berbasis problem based learning $(P B L)$ pada Pembelajaran Matematika di Sekolah Dasar. Secara khusus ditujukan untuk menguji kelayakan produk yang dikembangkan pada aspek: 1) media, 2) meteri, 3) strategi pembelajaran, dan 4) evaluasi pembelajaran. Jenis penelitian ini secara umum penelitian dan pengembangan. Jenis penelitian pada artikel ini evaluatif kualitatif. Data diperoleh dari penilaian validasi ahli materi, ahli media, strategi pembelajaran dan evaluasi pembelajaran. Teknik analisis data dengan metode alir dan komparasi konstan. Hasil penelitian, penilaian ahli media memperoleh nilai 75,5 dengan kategori layak, penilaian ahli materi memperoleh nilai 100 dengan kategori layak, sedangkan strategi pembelajaran memperoleh nilai 98,6 dengan kategori sangat layak dan evaluasi pembelajaran memperoleh nilai 98,7 dengan kategori sangat layak. Berdasarkan penilaian tersebut, dapat disimpulkan bahwa buku LKPD berbasis problem based learning $(P B L)$ layak digunakan sebagai media pembelajaran.
\end{abstract}

Kata kunci : buku LKPD, media, pembelajaran tatap muka terbatas, problem based learning $(P B L)$

\begin{abstract}
The research in this article generally aims to test the feasibility of problem-based learning (PBL) LKPD books in Mathematics Learning in Elementary Schools. Specifically, it is intended to test the feasibility of the product developed in the aspects of: 1) media, 2) material, 3) learning strategy, and 4) learning evaluation. This type of research is generally research and development. The type of research in this article is qualitative evaluative. The data was obtained from the validation assessment of material experts, media experts, learning strategies and learning evaluations. Data analysis technique with constant flow and comparison method. The results of the study, the assessment of media experts scored 75,5 in the appropriate category, the material expert assessment received a score of 100 in the appropriate category, while the learning strategy scored 98,6 in the very appropriate category and the learning evaluation scored 98,7 in the very appropriate category. Based on this assessment, it can be concluded that problem-based learning (PBL) LKPD books are suitable for use as learning media.
\end{abstract}

Keywords: LKPD books, media, limited face-to-face learning, problem based learning (PBL)

Copyright (c) 2022 Andi Arfianto, Sutama, Achmad Fathoni

$\triangle$ Corresponding author :

Email : Andi.arfianto.aa@gmail.com

DOI : https://doi.org/10.31004/basicedu.v6i1.1985

ISSN 2580-3735 (Media Cetak)

ISSN 2580-1147 (Media Online)

Jurnal Basicedu Vol 6 No 1 Tahun 2022 p-ISSN 2580-3735 e-ISSN 2580-1147 


\section{PENDAHULUAN}

Kurikulum 2013 adalah kurikulum berbasis kompetensi. Kompetensi itu dirancang untuk dicapai melalui proses pembelajaran berbasis penemuan (discovery learning) melalui kegiatan-kegiatan berbentuk tugas (project based learning), dan penyelesaian masalah(problem solving based learning) yang mencakup proses mengamati, menanya, mengumpulkan informasi,mengasosiasi, dan mengomunikasikan (Buku Tematik Terpadu Kurikulum 2013, Kemdikbud). Pembelajaran Problem Based Learning merupakan sebuah model pembelajaran yang menyajikan masalah kontekstual sehingga merangsang peserta didik untuk belajar memecahkan masalah dunia nyata (real world)(Triyanto \& Mustadi, 2020).

Berangsur menurunnya kasus Corona di wilayah Indonesia, berdasarkan keputusan bersama menteri pendidikan dan kebudayaan, menteri agama, menteri kesehatan dan menteri dalam negeri nomor 03/KB/2021, nomor 384 tahun 2021, nomor HK.01.08/MENKES/4242/2021, nomor 440 - 717 tahun 2021 tentang panduan penyelenggaraan pembelajaraan di masa pandemic covid-19. Selanjutnya menyusul intruksi gurbernur Jawa Tengah nomor 10 tahun 2021 implementasi pemberlakuan pembatasan kegiatan masyarakat leve 4, level 3 dan level 2 covid-19 di wilayan Jawa Tengah. Isi terkait intruksi gubernur terkait pelaksanaan pembelajaran tatap muka terbas yang diberlakukan untuk wilayah dengan level 2 dan 3. Bagi satuan pendidikan yang melaksanakan PTMT dilaksanakan dengan kapasitas maksimal 50\%. Dengan demikian pelaksanaan dilakukan secara hybrid atau blanded learning, dengan pembagian 50\% PTMT di sekolah dan 50\% PJJ dari rumah.

Sesuai dengan surat edaran tersebut, kegiatan pembelajaran di SD Muhammadiyah Program Khusus Kottabarat mengikuti kebijakan dari dinas tersebut yang semula 100\% PJJ menjadi 50\% PTM dan 50\% PJJ. pelaksanaan pembelajaran salah satunya memanfaatkan LKPD berbantuan media.

Pengembangan kemampuan berpikir kritis dapat meningkatkan keterampilan observasi, keterampilan berpikir, keterampilan mengambil keputusan, dan keterampilan menganalisis (Anazifa \& Djukri, 2017). Untuk meningkatkan kemampuan berpikir kritis pada peserta didik sangat dipengaruhi oleh penyajian bahan ajar (Siswa \& Ammy, 2021). Hasil angket analisis kebutuhan siswa diduga kurangnya keterampilan berpikir krisis pada peserta didik disebabkan karena penyajian bahan ajar yang kurang menarik dan penyajian materi yang kurang sistematis(Dole, Bloom, \& Doss, 2017).

Kemampuan berpikir kritis dapat diberdayakan melalui pembelajaran Problem Based Learning yang dikemas secara menarik sehingga meningkatkan minat belajar matematika dan motivasi belajar peserta didik (Education et al., 2021). Hasil analisis kebutuhan siswa, peserta didik lebih tertarik dengan belajar secara mandiri mengeksplorasi potensi yang dimiliki melalui pemecahan - pemecahan masalah sesuai kehidupan nyata(Maryam, 2016). Hasil penelitian (Dolmans, Loyens, Marcq, \& Gijbels, 2016) menyimpulkan bahwa PBL dapat mengembangkan atau meningkatkan keterampilan berpikir kreatif yang selanjutnya berkorelasi signifikan dengan hasil belajar.

Berdasarkan uraian tersebut, penelitian pada artikel ini secara umum bertujuan untuk menguji kelayakan buku LKPD berbasis problem based learning ( $P B L$ ) pada Pembelajaran Matematika di Sekolah Dasar. Secara khusus ditujukan untuk menguji kelayakan produk yang dikembangkan pada aspek: 1) media, 2) materi, 3) strategi pembelajaran, dan 4) eveluasi pembelajaran. Jenis penelitian ini secara umum penelitian dan pengembangan.

\section{METODE PENELITIAN}

Secara umum, jenis penelitian ini penelitian dan pengembangan. Pengembangan dilakukan dengan modifikasi model Borg \& Gall (Sutama, 2018). Tahapan pengembangan meliputi, 1) studi pengembangan (studi pustakan dan survei lapangan, serta penyusunan draf produk), 2) pengembangan (uji coba terbatas dan 
uji coba lebih luas), dan 3) pengujian produk secara empiris. Jenis penelitian pada artikel ini evaluatif kualitatif.

Subjek penelitian, uji coba terbatas adalah guru dan siswa kelas V SD Muhammadiyah 2 Kauman sebanyak 1 guru dan 10 siswa. Uji coba selanjutnya lebih luas subjeknya yaitu guru dan siswa kelas V SD Muhammadiyah 2 Kauman Surakarta sebanyak 1 guru dan 26 siswa. Subjek ahli materi satu praktisi dan ahli media satu dosen.

Data diperoleh dari penilaian validasi ahli media, ahli materi, strategi pembelajaran dan eveluasi pembelajaran. Teknik analisis data dengan metode alir dan komparasi konstan.

Langkah-langkah analisis data kelayakan buku LKPD berbasis problem based learning (PBL) pada materi operasi bilangan pecahan KD 3.1 pembelajaran matematika untuk kelas V di SD Muhammadiyah 2 Kahuman Surakarta, yaitu: 1) Mengubah penilaian dalam bentuk kualitatif menjadi kuantitatif dengan ketentuan skor 5 untuk kriteria sangat baik, 4 untuk kriteria baik, 3 untuk kriteria cukup baik, 2 untuk kriteria tidak baik, dan 1 untuk kriteria sangat tidak baik; 2) Setelah data terkumpul, kemudian menghitung skor ratarata; dan 3) Mengubah skor rata-rata menjadi nilai kualitataif berdasarkan kriteria penilaian.

Tabel 1.Konversi Skor Total Kelayakan Oleh Ahli Media, Ahli Materi, Strategi Pembelajaran dan Evaluasi Pembelajaran

\begin{tabular}{llll}
\hline No & Skor & Nilai & Kategori \\
\hline 1. & $\mathrm{X}>81,8$ & A & Sangat Baik \\
\hline 2. & $60,6<\mathrm{X} \leq 81,8$ & $\mathrm{~B}$ & Baik \\
\hline 3. & $39,4<\mathrm{X} \leq 60,6$ & $\mathrm{C}$ & Cukup Baik \\
\hline 4. & $18,2<\mathrm{X} \leq 39,4$ & $\mathrm{D}$ & Tidak Baik \\
\hline 5. & $\mathrm{X} \leq 18,2$ & $\mathrm{E}$ & Sangat Tidak Baik \\
\hline
\end{tabular}

Penelitian pengembangan buku LKPD berbasis problem based learning (PBL) ditentukan dengan layak apabila hasil penilaian dari masing-masing aspek diperoleh nilai minimal baik. Prosedur penelitian diilustrasikan pada gambar 1 .

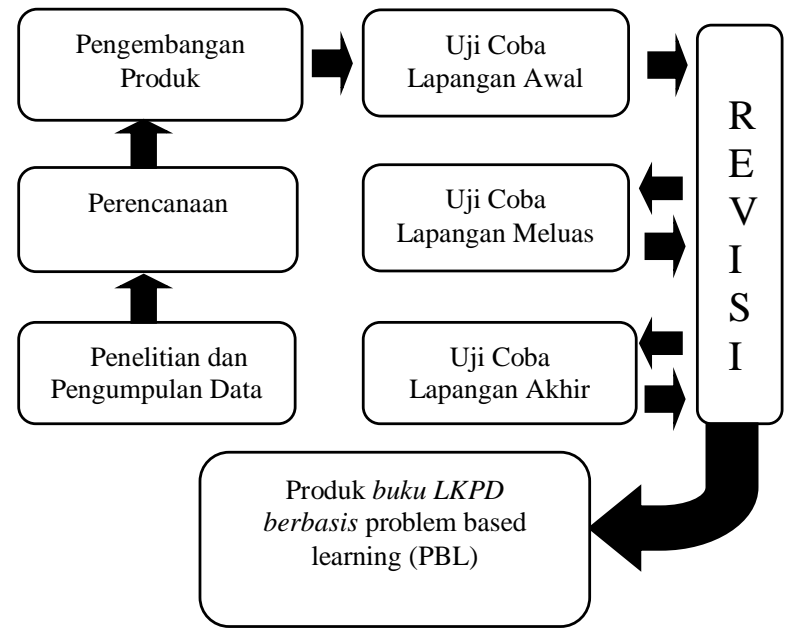

Gambar 1. Prosedur Penelitian 


\section{HASIL DAN PEMBAHASAN}

Model pembelajaran berbasis masalah akan berlangsung baik apabila siswa sudah memiliki kemampuan berpikir kritis terhadap suatu fenomena(Siew \& Chin, 2009). Menurut Arends (2008:41) PBL merupakan model pembelajaran yang menyuguhkan berbagai situasi bermasalah yang autentik dan bermakna kepada peserta didik, yang dapat berfungsi sebagai batu loncatan untuk investigasi dan penyelidikan.

Hasil penelitian pendahuluan digunakan sebagai pertimbangan dan dasar pengembangan LKPD. Langkah ini perlu dilakukan sebab penelitian pengembangan ini menguji cobakan suatu bahan ajar berupa LKPD berbasis Problem Based Learning yang pengembangannya harus didasarkan pada data empiris tentang profil dan subjek yang diteliti(Kuswanto \& Radiansah, 2018). Berdasarkan hasil analisis angket kebutuhan peserta didik dan pendidik serta hasil observasi proses pembelajaran.

Berdasarkan analisis kebutuhan tersebut maka diperlukan pengembangan LKPD untuk mengatasi permasalahan yang ada sehingga dapat melibatkan peserta didik secara aktif dan menjadikan pembelajaran yang lebih menarik dan menyenangkan namun juga bermakna (Siagian, 2021). LKPD yang dikembangkan adalah LKPD berbasis Problem Based Learning yang mampu meningkatkan kemampuan berpikir kritis peserta didik(Utia \& Fauzi, 2021). Hal tersebut bertujuan agar siswa dapat berpartisipasi dalam menghubungkan antar ilmu pengetahuan saat proses pembelajaran berlangsung. Hasil pengembangan ini berupa buku LKPD berbasis problem based learning (PBL) untuk kelas V SD Muhammadiyah 2 Kahuman, Surakarta.

Buku pelajaran yang dikembangkan merupakan buku LKPD berbasisi problem based learning (PBL) yang memuat materi pembelajaran operasi bilangan pecahan $K D 3.1$ pembelajaran matematika untuk kelas $V$. Desain dan pengembangan buku dilakukan dengan analisis persyaratan, desain dan pengembangan, implementasi serta evaluasi yang di lakukan pada setiap tahap (Rabiman, Nurtantp, 2020) menunjukkan hasil yang baik pada implementasi pembelajaran matematika di sekolah dasar. Alasan yang mendasar dalam pemilihan buku ini, berdasarkan penelitian Hani Ervina Pansa (2017) pengembangan buku LKPD dinilai cukup efektif meningkatkan pengetahuan, sikap dan ketrampilan anak. Sedangkan basis problem based learning (PBL) merujuk pada pemikiran (Philip Yenawine, 2013), bahwa tahapan pembelajaran problem based learning efektif digunakan dibandingkan dengan pembelajaran tradisional. Hal tersebut sesuai dengan harapan dalam proses pembelajaran matematika.

Buku LKPD berbasis problem based learning (PBL) terdiri dari 3 komponen, yaitu bagian cover, isi dan lembar evaluasi (Fravitasari, 2018). Bagian cover termuat keterangan mata pelajaran, sub materi dan pembelajaran serta judul materi pembahasan. Bagian isi memuat materi pembelajaran yang disajikan dengan pembahasan dan latihan soal dengan alur tahapan problem based learning (PBL). Bagian lembar evaluasi berisi soal-soal latihan sebagai tolak ukur pemahaman siswa terhadap materi yang disajikan melalui buku LKPD tersebut. Buku LKPD berbasis problem based learning (PBL) dibuat 1 buku setiap kompetensi dasar (KD) dan dicetak sebanyak siswa, dengan tujuan dalam pelaksanaan proses pembelajaran siswa dikelas dapat dilakukan dengan cara diskusi sehingga dapat meningkatkan pengetahuan siswa serta mengembangkan sikap dan ketrampilan siswa melalui proses diskusi dan dilakukan melalui tahapan problem based learning (PBL).

Pembelajaran matematika pada kurikulum 2013 yang terpisah dengan tematik menggunakan buku LKPD berbasis problem based learning (PBL) dilakukan dengan proses pembelajaran yang melibatkan lembar kerja siswa sebagai media belajar dan strategi berbasis masalah sebagai langkah-langkah pembelajarannya (Sam \& Qohar, 2016). Langkah pembelajaran dalam berbasis problem based learning (PBL) antara lain a) orientasi peserta didik pada masalah b) mengorganisasikan peserta didik untuk belajar c) membimbing penyelidikan individu maupun kelompok d) mengembangkan dan menyajikan hasil karya e) menganalisis dan mengevaluasi pemecahan masalah. Buku LKPD berbasis problem based learning (PBL) tersebut dapat membantu optimalisasi dalam proses pembelajaran.

Buku LKPD yang dikembangkan dibuat dengan bentuk kertas F4 dan dicetak dengan kerta HVS 
dengan ukuran huruf $14 \mathrm{pt}$ dengan bentuk huruf times new roman. Hal tersebut bertujuan agar mudah dipahami dan menarik dilihat untuk siswa kelas V (kelas atas), selain itu sejalan dengan penelitian Sitepu (2012) yang menyebutkan bahwa ukuran buku pelajaran untuk kelas atas tingkat sekolah dasar adalah A4, A5, atau F4.

Penelitian yang dilakukan oleh Prastowo, (2011) temuan ini menunjukan bahwa penggunaan simulasi dan lembar kerja yang dikembangkan memiliki dampak pada pengembangan kemampuan berpikir kritis peserta didik yang berada di antara fitur panggung formal dari mereka. Hasil analisis menunjukan rerata peringkat dan jumlah skor perbedaan antara pretest dan posttes disadari bahwa peningkatan peserta didik untuk mengingat pengetahuan mereka(Winangun, 2021). Dengan demikian dapat dilihat bahwa penelitian ini memberikan pembaharuan dari penelitian sebelumnya, bahwasannya pada indikator "memberikan penjelasan lebih lanjut"pada pemberian LKPD membuat peserta didik lebih mudah memahami dalam mengerjakan soal ataupun memahami materi dalam LKPD karena dalam pengulanan ini membuat peserta didik mendapatkan pengalaman secara berulang dan hal ini dapat mengembangkan kemampuan berpikir kritis pada peserta didik (Wati, 2018).

Efektivitas suatu bahan ajar dapat dilihat dari meningkatnya hasil belajar peserta didik setelah menggunakan bahan ajar yang diberikan sebagaimana pendapat Sugiyono (2013) yang mengemukakan bahwa mengukur efektivitas bahan/media pembelajaran dapat dilihat dari 1) mudahnya bahan atau media pembelajaran tersebut di implementasikan, 2) suasana belajar menjadi kondusif, 3) hasil pembelajaran meningkat. Oleh karena itu, untuk mengetahui efektivitas penggunaan LKPD berbasia Problem Based Learning dapat dikatakan efektif untuk meningkatkan kemampuan berpikir kritis peserta didik jika hasil belajar peserta didik sesudah menggunakan LKPD berbasis Problem Based Learning lebih tinggi dibandingkan sebelum menggunakan LKPD berbasis Problem Based Learning(Anazifa \& Djukri, 2017).

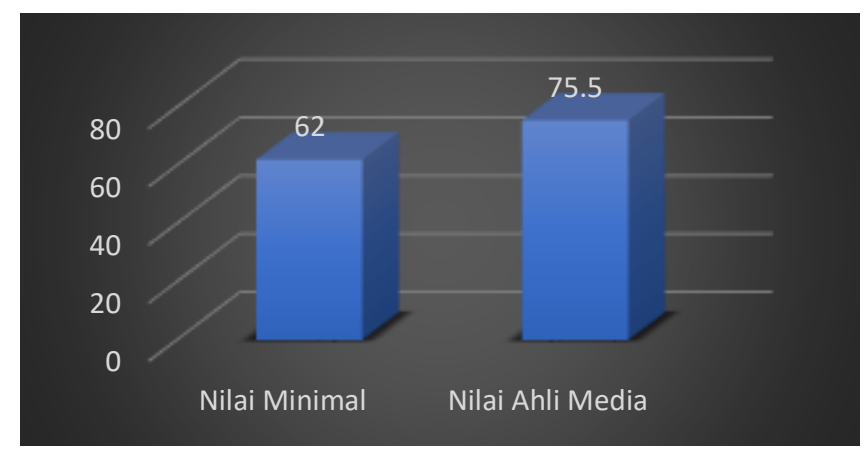

Gambar 2. Hasil Validasi Ahli Media

Berdasarkan gambar 2, hasil penilaian ahli media medapatkan skor akhir 75,5 dengan nilai kategori "B" (baik). Hal ini menunjukkan bahwa produk penelitian dinyatakan layak, karena nilai yang diperoleh melebihi nilai minimal, yaitu $62>60,6$.

Hasil penilaian ahli materi disajikan pada gambar 3. Nilai yang diperoleh dari ahli media adalah 100 dengan kategori "A" (sangat baik), artinya nilai tersebut lebih tinggi dari ketentuan skor minimal yaitu $62>$ 60,6. Produk penelitian dan pengembangan berupa buku LKPD berbasisi problem based learning (PBL) ini dinyatakan layak oleh ahli materi. 


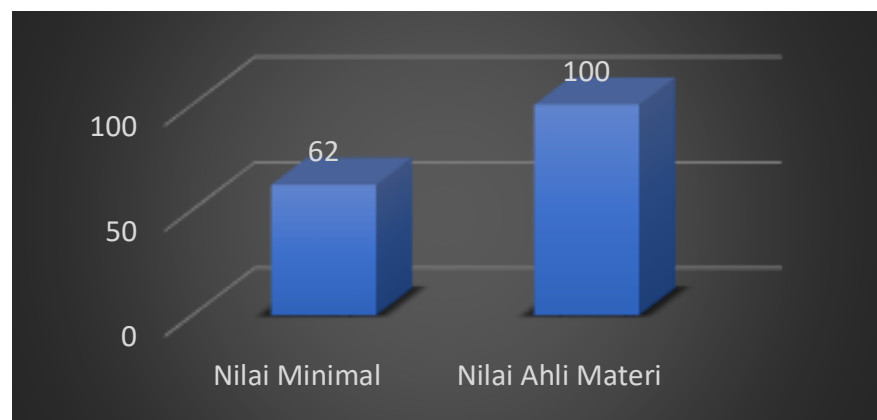

Gambar 3. Hasil Validasi Ahli Materi

Hasil penilaian dari ahli strategi pembelajaran disajikan pada gambar 4. Skor yang diperoleh dari respon guru adalah 98,6 dengan "A" kategori "Sangat Baik", dengan demikian skor melebihi nilai minimal, yaitu $62>60,6$. Berdasarkan data tersebut dapat disimpulkan bahwa buku LKPD berbasis problem based learning $(P B L)$ layak digunakan sebagai media pembelajaran.

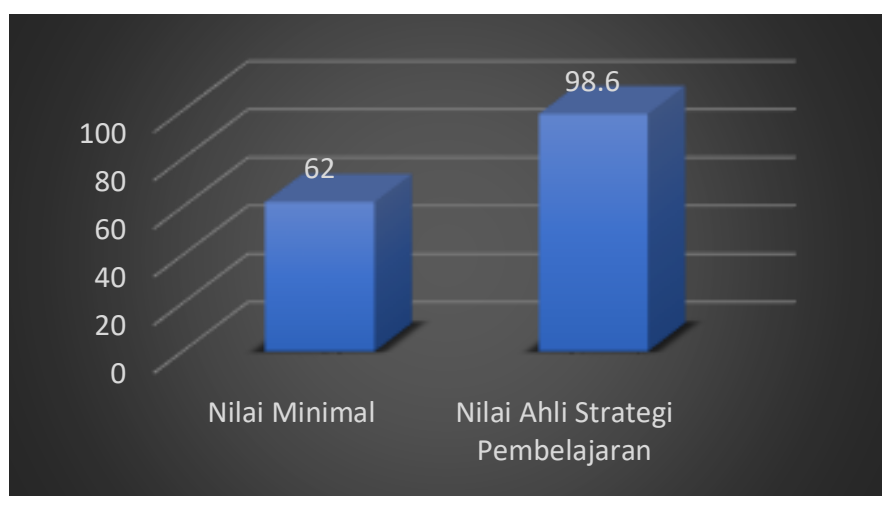

Gambar 4. Hasil Validasi Ahli Strategi Pembelajaran

Hasil penilaian dari respon siswa disajikan pada gambar 5. skor evaluasi pembelajaran adalah 98,7 dengan nilai "A" kategori sangat baik, yang artinya melebihi batas ambang skor minimal yang harus diperoleh, yaitu $62>60,6$. Berdasarkan hal tersebut dapat disimpulkan bahwa buku LKPD berbasis problem based learning $(P B L)$ layak digunakan sebagai media pembelajaran.

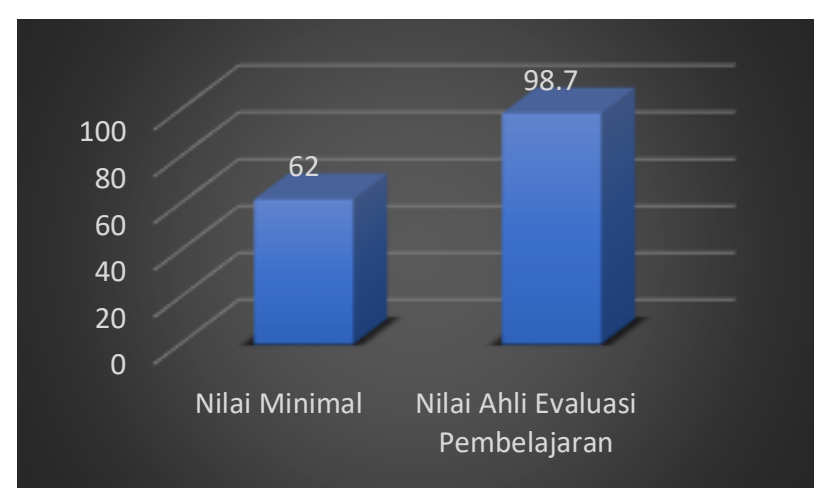

Gambar 5. Hasil Validasi Ahli Evaluasi Pembelajaran

Buku LKPD berbasis problem based learning (PBL) secara keseluruhan dapat di simpulkan bahwa buku tersebut layak dijadikan sebagai media pembelajaran matematika di SD(Saleh, 2013). Media tersebut juga dapat dijadikan sebagai salah satu alternatif referensi yang solutif untuk digunakan pada proses 
pembelajaran matematika untuk kelas V. Hal tersebut dikarenakan penerapan pembelajaran menggunakan problem based learning (PBL) dapat meningkatkan berfikir kritis siswa di sekolah dasar. Selain itu penggunaan simulasi dan lembar kerja yang dikembangkan memiliki dampak pada pengembangan kemampuan berpikir kritis peserta didik yang berada di antara fitur panggung formal dari mereka. Prastowo, (2011).

Pembelajaran matematika di sekolah dasar menggunakan buku LKPD berbasis problem based learning $(P B L)$ sudah mencakup materi matematika di kurikulum 2013 yang dapat menjelaskan lebih detail dan terstruktur melalui penyajiannya yang berbasis problem based learning $(P B L)$, sehingga dapat membantu pemahaman siswa terhadap materi pembelajaran, serta dapat meningkatkan berfikir kritis pada siswa Etherington (2011). Pembelajaran yang dilakukan dengan buku LKPD berbasis problem based learning (PBL) menjadikan siswa mudah terlibat dalam berpikir kritis dan memunculkan sinergi yang baik antara kreativitas dan pemikiran kritis sehingga memungkinkan terjadinya pembelajaran yang optimal (Selcuk, Caliskan, \& Sahin (2013).

\section{KESIMPULAN}

Kebijakan kegiatan pembelajaran tatap muka terbatas (PTMT) di sekolah dengan terbatas pada masa pandemi mengakibatkan pemerintah dan lembaga pendidikan terkait untuk membuat rekayasa alternatif pembelajaran. Penerapan pembelajaran PTMT 50\% perlu strategi yang tepat untuk pengelolan pembelajaran terkait kebijakan tersebut. Pengelolaan di sekolah maupun yang belajar dari rumah (daring). Model buku LKPD berbasis problem based learning $(P B L)$ hasil pengembangan layak digunakan pada kegiatan pembelajaran tatap muka terbatas (PTMT) di Sekolah Dasar. Hal ini telah teruji secara teoritis maupun empiris dari ahli media, ahli materi, ahli strategi pembelajaran dan ahli evaluasi pembelajaran. Apabila buku LKPD berbasis problem based learning (PBL) digunakan, maka proses pembelajaran akan lebih baik dan meningkatkan berfikir kritis siswa. Hal ini sesuai dengan hasil penelitian (Kusminah, 2012) menyatakan bahwa LKPD sangat baik, menarik dan mudah digunakan dalam proses pembelajaran.

\section{UCAPAN TERIMAKASIH}

Kami berterima kasih kepada pimpinan Sekolah Dasar Muhammadiyah 2 Kauman, Surakarta karena telah menerima kami untuk melakukan penelitian tentang pengembangan buku LKPD berbasis problem based learning $(P B L)$ dan semua pihak yang sudah membantu dalam keberhasilan penyusunan artikel ini.

\section{DAFTAR PUSTAKA}

Anazifa, R. D., \& Djukri. (2017). Project- Based Learning And Problem- Based Learning: Are They Effective To Improve Student's Thinking Skills? Jurnal Pendidikan Ipa Indonesia, 6(2), 346-355. Https://Doi.Org/10.15294/Jpii.V6i2.11100

Arends, R. (2008). Learning To Teach. (H. Prajitno \& S. Mulyani, Trans.). New York: Mcgraw Hill Companies.

Dole, S., Bloom, L., \& Doss, K. K. (2017). Engaged Learning: Impact Of Pbl And Pjbl With Elementary And Middle Grade Students. Interdisciplinary Journal Of Problem-Based Learning, 11(2), 7-11. Https://Doi.Org/10.7771/1541-5015.1685

Dolmans, D. H. J. M., Loyens, S. M. M., Marcq, H., \& Gijbels, D. (2016). Deep And Surface Learning In Problem-Based Learning: A Review Of The Literature. Advances In Health Sciences Education, 21(5), 1087-1112. Https://Doi.Org/10.1007/S10459-015-9645-6 
Education, E., Fadil, K., Kurnia, D., Ibn, U., Bogor, K., Barat, J., ... Barat, J. (2021). Jurnal Basicedu, 5(1), $19-29$.

Etherington, M. B. (2011). Investigative Primary Science: A Problem-Based Learning Approach. Australian Journal Of Teacher Education (Online), 36(9), 53-74.

Fravitasari, A. F. (2018). Penerapan Model Pembelajaran Problem Based Learning Untuk Meningkatkan Proses Dan Hasil Belajar Muatan Ipa Tema 8 Sub Tema 1 Kelas 4. Journal For Lesson And Learning Studies, 1(3), 157-164. Https://Doi.Org/10.23887/Jlls.V1i3.15401

Kusminah. (2012). The Birth Of The Journal Of Educational Research. Journal Of Educational Research, 38(5), 321-325. Https://Doi.Org/10.1080/00220671.1945.10881349

Kuswanto, J., \& Radiansah, F. (2018). Media Pembelajaran Berbasis Android Pada Mata Pelajaran Sistem Operasi Jaringan Kelas Xi. Jurnal Media Infotama, 14(1). Https://Doi.Org/10.37676/Jmi.V14i1.467

Maryam, M. (2016). Pengaruh Motivasi Dalam Pembelajaran. Lantanida Journal, 4(2), 88-97. Retrieved From

Https://Jurnal.Ar-

Raniry.Ac.Id/Index.Php/Lantanida/Article/Download/1881/1402\%0ahttps://Media.Neliti.Com/Media/Pu blications/287678-Pengaruh-Motivasi-Dalam-Pembelajaran-Dc0dd462.Pdf

Moeller, M., Cutler, K., Fiedler, D., \& Weier, L. (2013). Visual Thinking Strategies = Creative And Critical Thinking. Phi Delta Kappan, 95(3), 56-60. Https://Doi.Org/10.1177/003172171309500312

Philip Yenawine. (2013). Understanding Visual Literacy : The Visual Thinking Startegies Approach.

Saleh, M. (2013). Strategi Pembelajaran Fiqh Dengan Problem-Based Learning. Jurnal Ilmiah Didaktika, 14(1), 190-220. Https://Doi.Org/10.22373/Jid.V14i1.497

Sam, H. N., \& Qohar, A. (2016). Pembelajaran Berbasis Masalah Berdasarkan Langkah - Langkah Polya Untuk Meningkatkan Kemampuan Menyelesaikan Soal Cerita Matematika. Kreano, Jurnal Matematika Kreatif-Inovatif, 6(2), 156. Https://Doi.Org/10.15294/Kreano.V6i2.5188

Selcuk, G. S., Caliskan, S., \& Sahin, M. (2013). A Comparison Of Achievement In Problem-Based-Strategic And Traditional Learning Classes In Physics. International Journal On New Trends In Education And Their Implications, 4(1), 14.

Siagian, G. (2021). Jurnal Basicedu. Jurnal Basicedu, 5(3), 1683-1688.

Siew, N. M., \& Chin, M. K. (2009). The Effects Of Problem Based Learning With Cooperative Learning On Preschoolers' Scientific, 100-112.

Siswa, B. M., \& Ammy, P. M. (2021). Jurnal Basicedu, 5(5), 3242-3249.

Sutama. (2018). Prof. Dr. Sutama, M.Pd.

Triyanto, Y., \& Mustadi, A. (2020). The Effect Of Problem-Based Learning Model Assisted By Lift The Flap Book: Enhancing Reading Motivation Of 3rd Grade Students. Journal For The Education Of Gifted Young Scientists, 8(1), 151-166. Https://Doi.Org/10.17478/Jegys.664120

Utia, R., \& Fauzi, A. (2021). The Validity Of The Integrated Physics Ebook On Landslide Disaster Mitigation Materials Based On A Problem Based Learning Model. International Journal Of Progressive Sciences And Technologies, 25(1), 630. Https://Doi.Org/10.52155/Ijpsat.V25.1.2731

Wati, Y. I. (2018). Penerapan Model Pbl (Problem Based Learning) Pada Pembelajaran Ipa Kelas 4 Mi Nurur Rohmah Tentang Energi Panas. Http://Eprints.Umsida.Ac.Id/, (20), 1-14.

Winangun, I. M. A. (2021). Project Based Learning: Strategi Pelaksanaan Praktikum Ipa Sd Dimasa Pandemi Covid-19. Edukasi: Jurnal Pendidikan Dasar, 2(1), 14. Retrieved From Http://Stahnmpukuturan.Ac.Id/Jurnal/Index.Php/Edukasi/Article/View/1388 